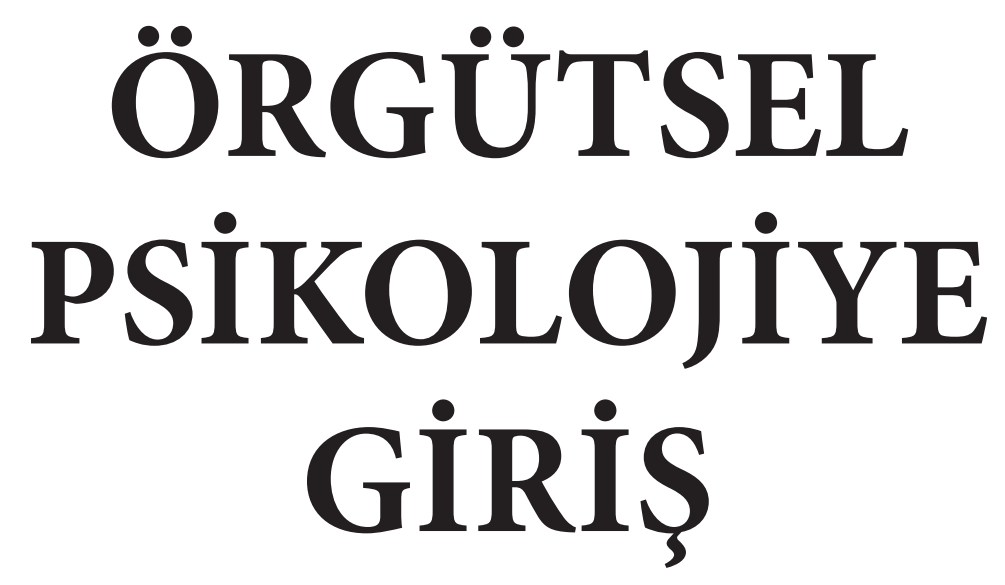

Doç. Dr. Hakan Vahit ERKUTLU 


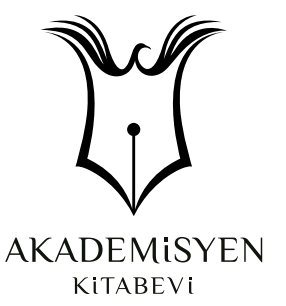

(C) Copyright 2019

Bu kitabın, basım, yayın ve satış hakları Akademisyen Kitabevi A.Ş.'ne aittir. Anılan kuruluşun izni alınmadan kitabın tümü ya da bölümleri mekanik, elektronik, fotokopi, manyetik kağıt ve/veya başka yöntemlerle çoğaltılamaz, basılamaz, dağıtılamaz. Tablo, şekil ve grafikler izin alınmadan, ticari amaçh kullanılamaz. Bu kitap T.C. Kültür Bakanh̆̆̆ bandrolü ile satılmaktadır.

ISBN Sayfa ve Kapak Tasarım

978-605-258-248-0 Akademisyen Dizgi Ünitesi

Kitap Adı Yayıncı Sertifika No

Örgütsel Psikolojiye Giriş $\quad 25465$

Yazar Baskı ve Cilt

Doç. Dr. Hakan Vahit Erkutlu Bizim Dijital Matbaa

\author{
Yayın Koordinatörü Bisac Code \\ Yasin DİLMEN BUS085000 \\ DOI \\ 10.37609/akya.737
}

\title{
GENEL DAĞITIM
}

Akademisyen Kitabevi A.Ş.

\author{
Halk Sokak 5 / A \\ Yenişehir / Ankara \\ Tel: o312 4311633 \\ siparis@akademisyen.com
}

\section{www.akademisyen.com}




\section{ÖNSÖZ}

Örgütsel psikoloji, psikolojinin bilgi birikimini bireyin çalışma yaşamını açıklamada kullanır ve bireyin çalışma yaşamına ilişkin yeni bilgiler üretir. $\mathrm{Bu}$ bilim dalının kapsamına giren konular arasında; çalışanın tatminini ve verimini arttırma, çalışanın işiyle ve çalıştığ işletmeyle bütünleşmesi, zamanı geldiğinde ise sağlıklı biçimde ayrılmasını sağlama, iş başında yaşayabileceği stres ve sıkıntıyı azaltmaya yönelik çabaların tümü örnek olarak verilebilir.

$\mathrm{Bu}$ çabalar çalışan ile işi arasında en iyi uyuma ulaşmaya yöneliktir. Bunun yolu ise insan kaynakları yönetimi'ninde konuları arasında bulunan iş analizi, personel seçimi, performans değerlemesi, işe güdüleme, personel eğitimi ve iş çevresi koşullarının çalışana uyarlanma süreçlerinde etkinliğin sağlanmasından geçer.

Örgütsel psikoloji günümüz çalışma yaşamında önemi giderek artan akademik bir disiplin ve bir uygulama alanıdır. 20. yüzyllın sonlarında, endüstride olan hızlı gelişim ve değişmeler, yeni teknolojiler ve artan rekabet koşulları, üretim ve yönetim biçiminde yenilikleri de beraberinde getirmiştir. $\mathrm{Bu}$ durum, çalışanların ve örgütlerin değişime ayak uydurmalarını ve yeniden yapılanmalarını zorunlu kılmış, insan kaynaklarının önemini, sosyal ve davranış bilimlerine olan gereksinimleri de artmıştır. Günümüzde örgütsel psikoloji, psikolojinin en çok rağbet gören alt dallarından biri durumuna gelmiştir.

Örgütsel psikolojinin ilgi alanı (a) insan davranışlarıyla ve (b) insanın da "işle ilgili" davranışlarıyla sınırlıdır. Çalışanların iş performansını ve iş doyumunu etkileyen faktörleri saptamak, onların performans ve doyumunu artırmaya yönelik yöntemler ve teknikler geliştirmek örgütsel psikolojinin temel araçları arasindadır.

Çalışma olgusu oldukça karmaşıktır ve içinde pek çok faktörü barındırmaktadır. $\mathrm{Bu}$ doğrultuda, çalışma yaşamının da pek çok unsuru bulunmaktadır: çalışmanın kendisi, yapılan işin doğası, çalışma ortam ve koşulları, çalışan birey ve özellikleri ayrı ayrı önemli olduğu kadar birbirleriyle de ilişki içindedir. Kitabın bölümlerinde tüm bu unsurlara kuramsal olarak yer verilmekte ve alanın uygulama yönü güçlü olması nedeniyle çalışma yaşamından güncel örnekler de incelenmektedir.

Kitabın 1. Bölümde örgütsel psikoloji kavramının tanımları, pozitif ve negatif boyutları ile gelişimi ele alınmıştır. 
İnsan kaynakları yönetimi, tarihsel gelişimi, özellikleri, önemi, amaçları ve işlevleri 2. Bölümde, motivasyon kavramı ve önemi ile motivasyon süreci ve kuramları 3. Bölümde; örgütsel vatandaşlık, işe adanma, işe gömülmüşlük, işe bağl1lık, psikolojik iyi oluş ve psikolojik sermaye gibi pozitif çalışan tutum ve davranışları 4. Bölümde ele alınmıştır. Ayrıca bu bölümde üretkenlik karşııı iş davranışları, işyeri nezaketsizliği, örgütlerde dedikodu ve söylenti, tükenmişlik, işyeri tatminsizliği ile örgütsel sinizm konuları da işlenmiş̧ir. 5. Bölümde ise örgütsel iletişim kavramının tanımları, süreci, türleri, amaç ve işlevleri ile yönetimi detaylı biçimde tartışılmıştır.

Daha önceden belirlenmiş amaç ve hedeflere ulaşmak için bir araya gelmiş, birbirleriyle bağımlı ve toplu hareket eden ve birden fazla bireyin oluşturduğu bir bütünlük olarak tanımlayabileceğimiz takım kavramı, türleri ve oluşum aşamaları 6. Bölümün konuları arasındadır. 7. Bölümde "bir grup insanı belirli amaçlar etrafında toplayabilme ve bu amaçları gerçekleştirmek için onları harekete geçirme beceri ve bilgilerinin toplamı" diye ifade edebileceğimiz liderlik kavramı ile klasik ve çağdaş liderlik kuramları tartışılmaktadır. Kitabın 8. Bölümünde örgüt üyelerinin örgütün menfaatlerini göz ardı ederek, kendilerine bireysel çıkar sağlamaya yönelik davranışları olarak tanımlanabilen örgütsel politika kavramı incelenmiştir. Örgütsel politika kavramının tanımları, ortaya çıkma nedenleri ve sonuçları ile kavramla ilişkili örgütlerde güç ve etkileme kavramlarına da bu bölümde yer verilmiştir.

Örgüt üyelerinin tutum ve davranışlarını biçimlendiren ve yönlendiren bir rehber olmanın yanında bir kontrol mekanizması işlevi de gören örgüt kültürü ile örgütsel yapı ve örgüt geliştirme 9. Bölümde incelenmektedir. Bu bölümde örgüt kültürünün unsurları, işlevleri, örgüt kültürünü açıklayan modeller ile örgüt yapısını oluşturan unsurlar, örgüt yapısı modelleri ve örgüt kültürünü geliştirme konuları ele alınmaktadır. 10. Bölümde insanın içinde bulunduğu ortamı olumsuz olarak değerlendirmesi sonucu içine düşmüş olduğu durum diye ifade edebileceğimiz stres kavramı, stres kaynakları, aşamaları ve yönetimi tartışılmaktadır.

Kitabın son bölümünde örgütsel adalet kavramı ele alınmıştır. Çalışanların görev dağılımı, mesaiye uyma, yetki verilmesi, ücret düzeyi, ödül dağıtımı gibi değişkenlere yönelik, yönetsel kararları değerlendirme süreci olarak tanımlanabilecek olan örgütsel adalet kavramının boyutları, kavramın temelini oluşturan kuramlar, kavramın öncülleri ve sonuçları tartışılan konular arasındadır.

Kitabın tamamlanmasında öğrenci ve meslektaş gibi pek çok kişinin doğrudan veya dolaylı katkıları olmuştur. Bunların hepsine teşekkür borçluyum. Ayrıca benim bu konularda yetişmemi sağlayan ve yol gösteren, bana olanak 
veren, beni eleştiren ve yol gösteren, konuları benimle tartışan değerli hocalarım Prof. Dr. Öznur Yüksel, Prof. Dr. İnci Erdem Artan, Prof. Dr. Azmi Yalçın, Prof. Dr. Mehmet Yusuf Yahyagil ve Prof. Dr. Mehmet Tomanbay'a saygılarımı ve teşekkürlerimi sunuyorum.

Diğer taraftan, göstermiş hoşgörü ve destek için rahmetli anneannem Hediye Demirkan'a ne kadar teşekkür etsem azdır.

Elinizdeki kitap, lisans ve lisansüstü öğrencilerin çalışma psikolojisi bilimi hakkında teorik bilgi edinmeleri açısından yol gösterici niteliktedir. Ayrıca, çalışma ortamında insan davranışını anlamak isteyen ve uygulamada bulunan kişilere de kitabın önemli ölçüde katkısı olacaktır. Hem ders hem de referans kitabı olma özelliği gösteren bu eserin okuyuculara faydalı olması dileğiyle.

Doç. Dr. Hakan Vahit Erkutlu 
- 


\section{IÇİNDEKİLER}

Önsöz ..iii

\section{BÖLÜM 1}

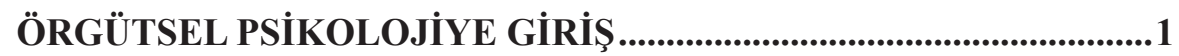

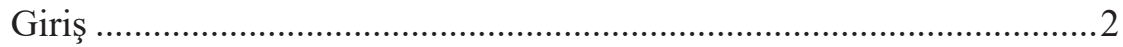

Örgütsel Psikoloji Tanımları .................................................................

Örgütsel Psikolojinin Pozitif Boyutları.................................................... 4

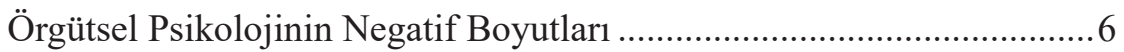

Örgütsel Psikolojinin Tarihçesi......................................................... 8

Yirminci Yüzyıl Başları: İlk Dönem Çalışmaları ................................. 8

Lillian Gilbreth ve Frank Gilbreth...............................................

Frederick Winslow Taylor .......................................................

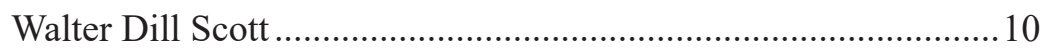

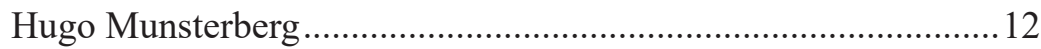

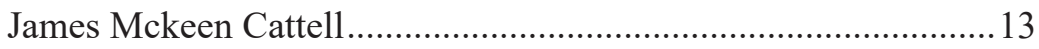

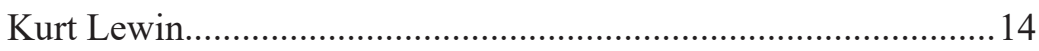

Birinci Dünya Savaşı Dönemi .......................................................16

Birinci Dünya Savaşı Sonrası Dönem (1920-1930) …………….......17

Büyük Bunalım Dönemi (1930-1940)...............................................20

İkinci Dünya Savaşı Dönemi (1941-1945) ...........................................21

İkinci Dünya Savaşı Sonrasından Günümüze .....................................22

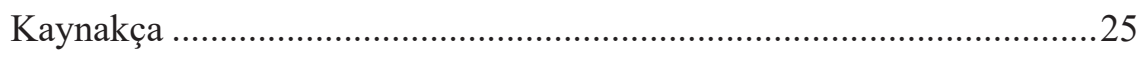

\section{BÖLÜM 2}

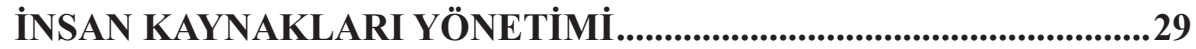

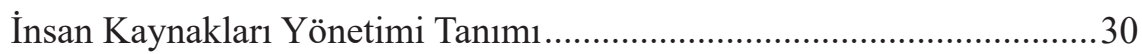

İnsan Kaynakları Yönetiminin Tarihsel Gelişimi .....................................30

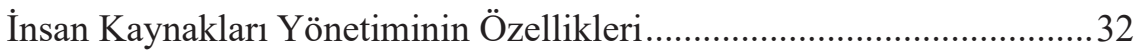

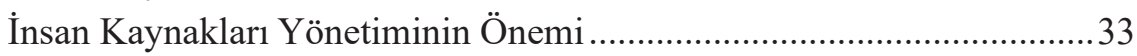

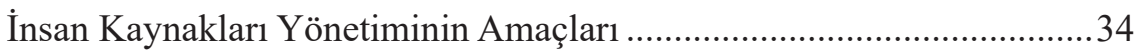

İnsan Kaynakları Yönetimi Uygulamalarının Faydaları...........................36

İnsan Kaynakları Yönetiminin Kapsamı ve İşlevleri..................................36

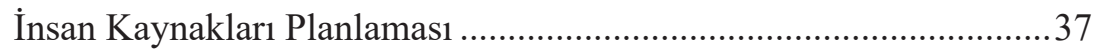




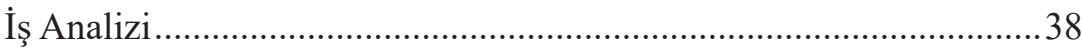

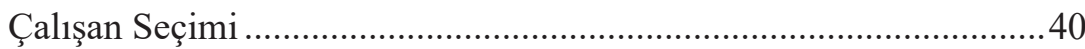

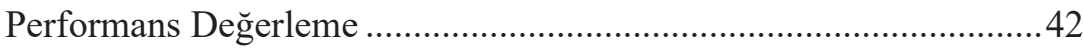

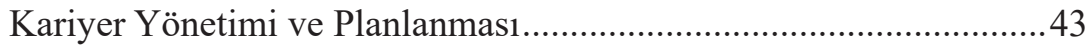

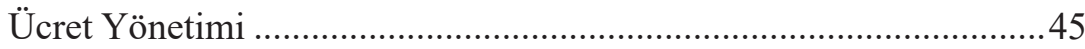

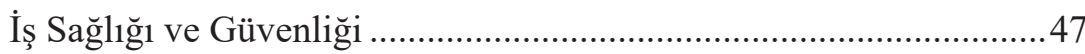

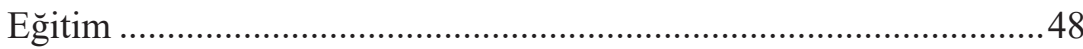

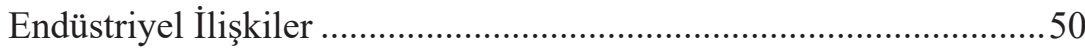

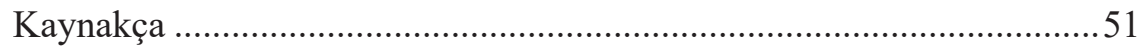

\section{BÖLÜM 3}

ÖRGÜTLERDE MOTIVASYON SÜRECI VE KURAMLARI .............53

Motivasyon Kavramının Tanımı ve Önemi ............................................54

Motivasyonun Örgütlerde Yönetici Açısından Önemi .........................54

Motivasyonun Örgütlerde Çalışan Açısından Önemi ..............................55

Motivasyonun Örgütlerde İşletme Açısından Önemi ...........................55

Motivasyon Sürecindeki Önemli Kavramlar ..........................................56

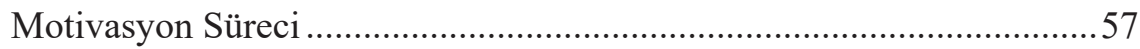

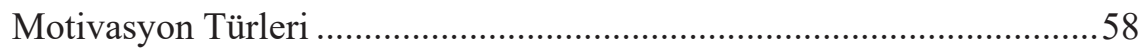

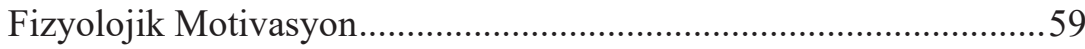

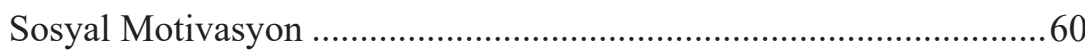

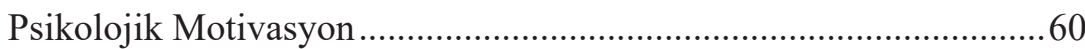

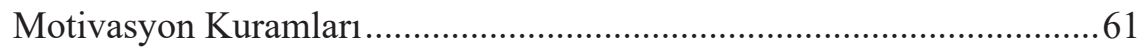

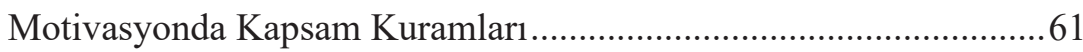

Maslow'un İhtiyaçlar Hiyerarşisi Kuram1........................................61

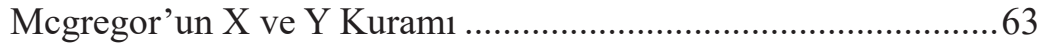

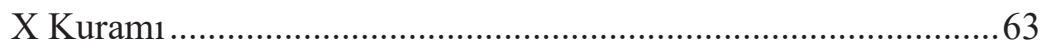

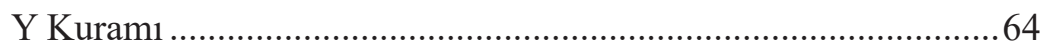

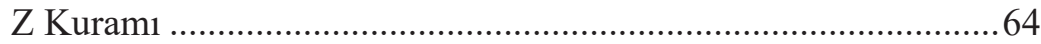

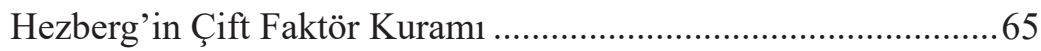

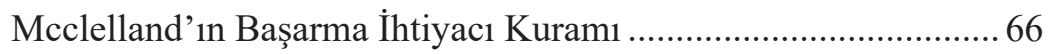

Alderfer'in Var Olma-İlişki Kurma-Gelişme

(Erg- Existence- Relatedness -Growth) Kuram1...............................68

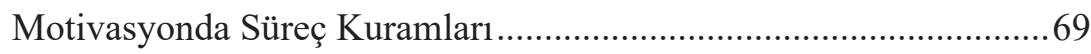

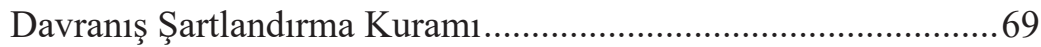

Bilişsel Değerlendirme Kuram1 ........................................................

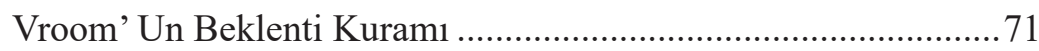

Lawler-Porter Motivasyon Modeli ................................................. 


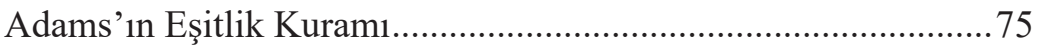

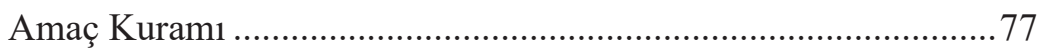

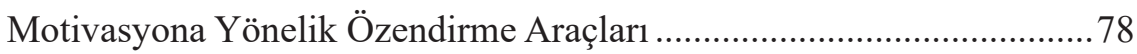

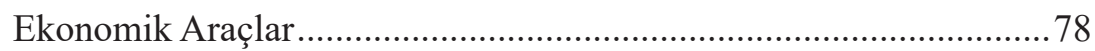

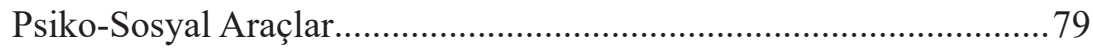

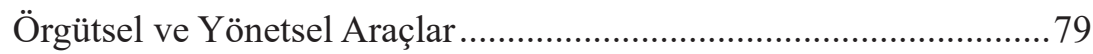

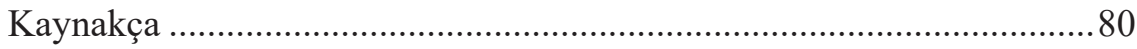

\section{BÖLÜM 4}

POZITIFF VE NEGATIF ÇALIŞAN TUTUM VE DAVRANIŞLARI ....83

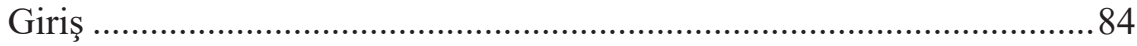

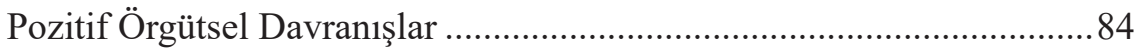

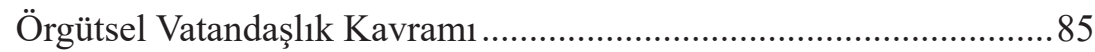

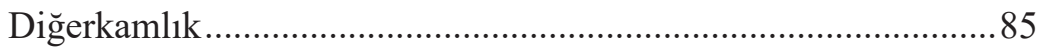

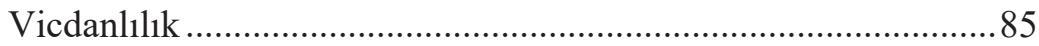

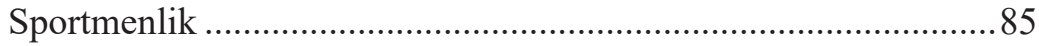

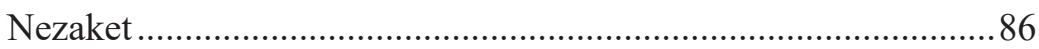

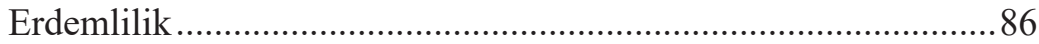

İşe Adanma (Work Engagement)....................................................... 87

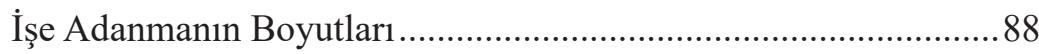

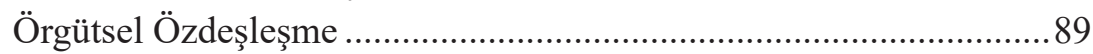

İşe Gömülmüşlük (Job Embeddedness) ………………………….....91

İşe Gömülmüşlük Boyutları ......................................................99

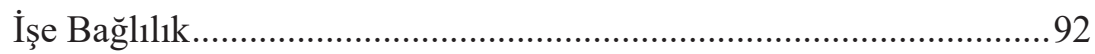

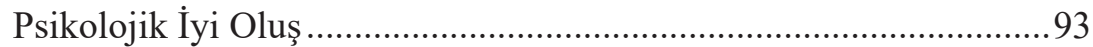

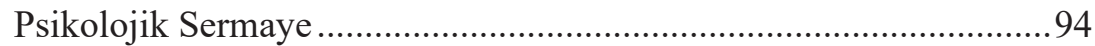

Psikolojik Sermayenin Bileşenleri ...............................................97

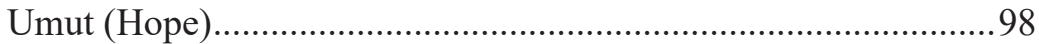

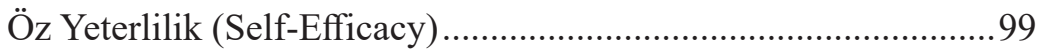

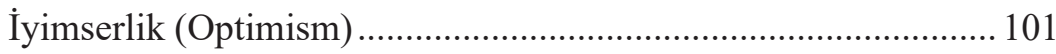

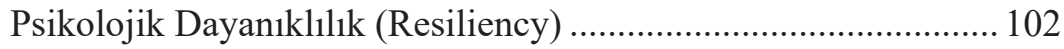

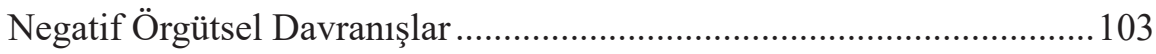

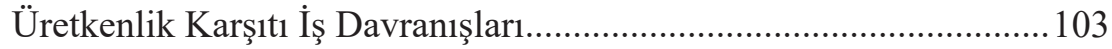

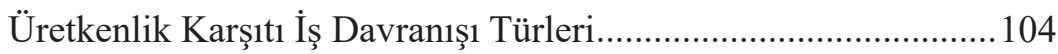

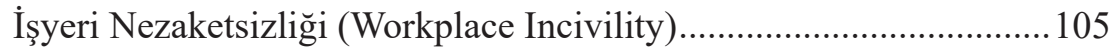

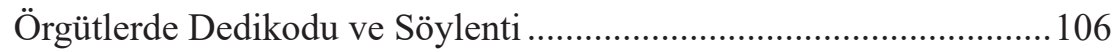

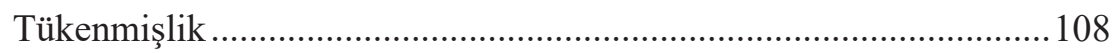

Tükenmişlik Sendromunun Önemi...............................................110

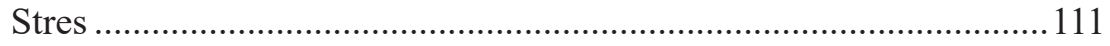




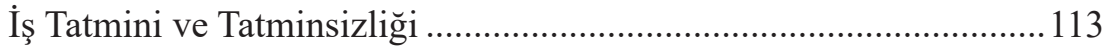

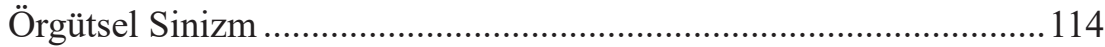

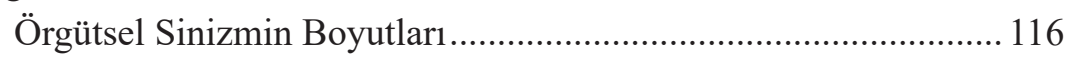

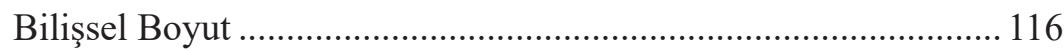

Duygusal Boyut...................................................................... 116

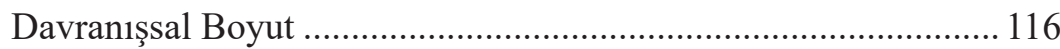

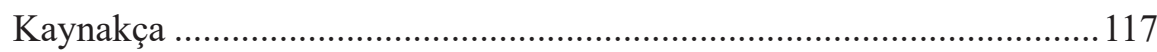

BÖLÜM 5

ÖRGÜTLERDE İLETISŞIM ..................................................................123

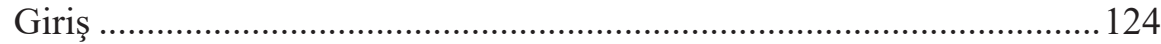

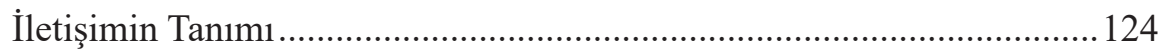

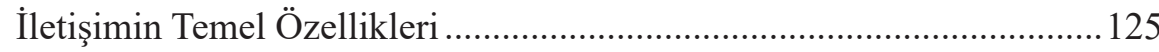

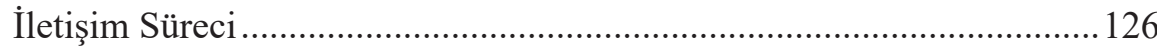

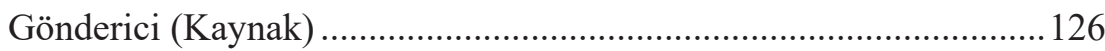

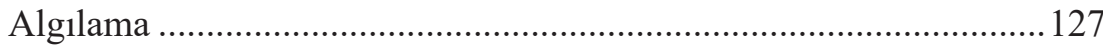

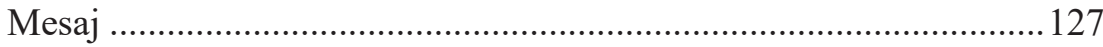

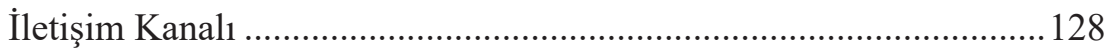

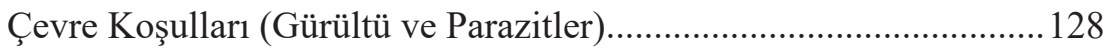

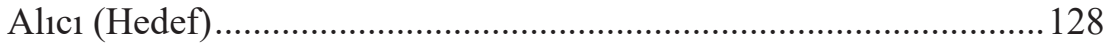

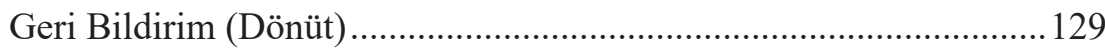

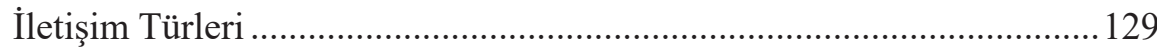

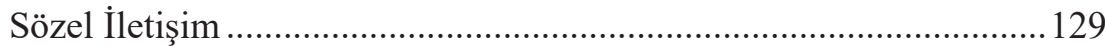

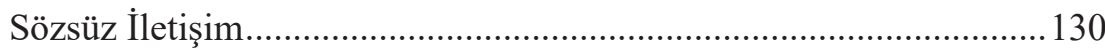

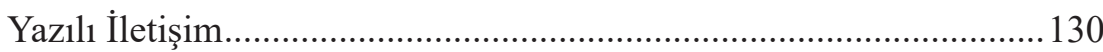

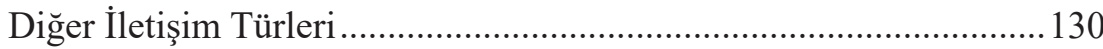

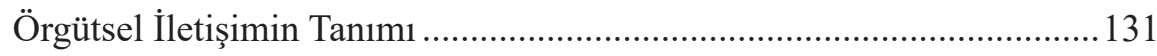

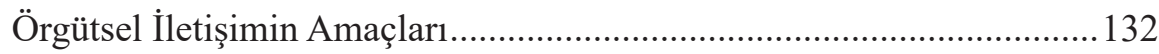

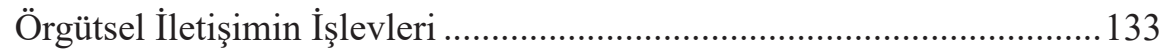

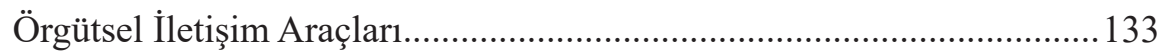

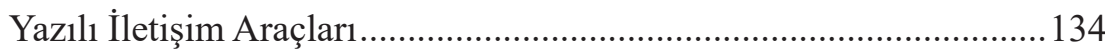

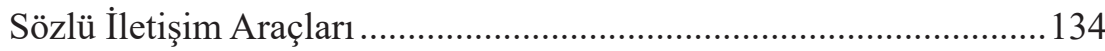

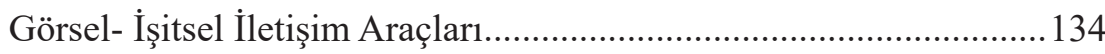

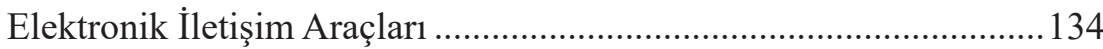

Örgütsel İletişim Kanalları ................................................................134

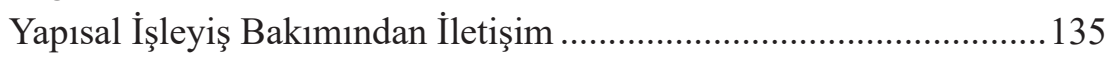

Mesaj Akış Yönü Bakımından İletişim..................................................135

Örgütsel İletişim Ağ Modelleri................................................................137 


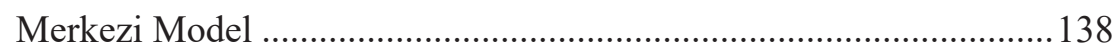

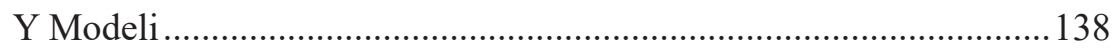

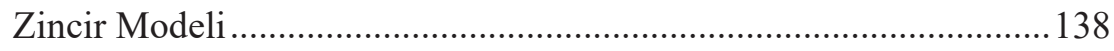

Dairesel (Çember) Model ................................................................138

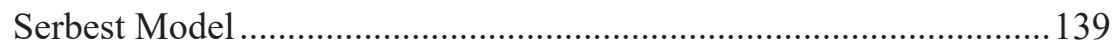

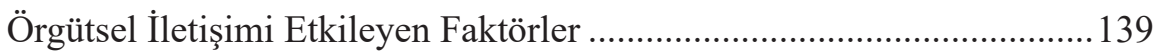

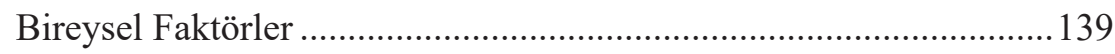

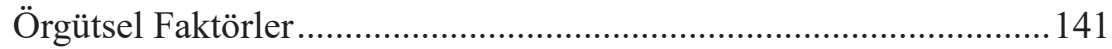

Örgütsel İletişimin Etkin Yönetimi...........................................................142

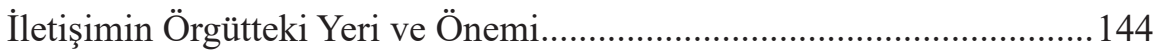

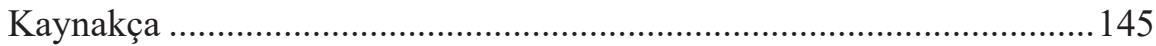

\section{BÖLÜM 6}

ÖRGÜTLERDE TAKIM SÜREÇLERİ ..................................................147

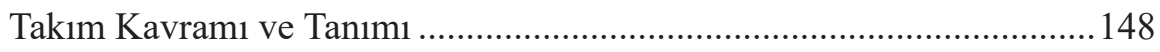

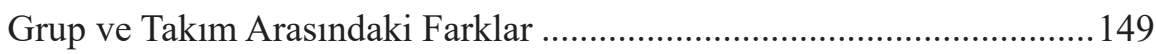

Takım Çalışması Kavramı ve Tanımı ......................................................151

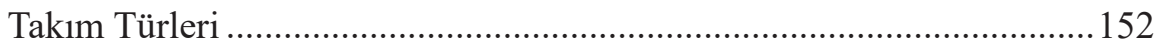

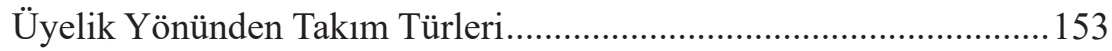

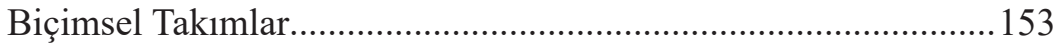

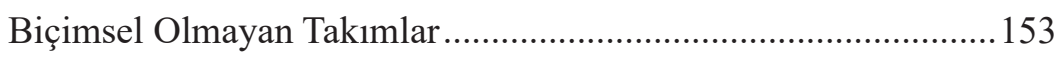

İşletme İçindeki İlişkiler Açısından Takım Türleri................................153

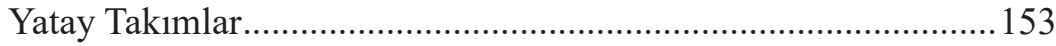

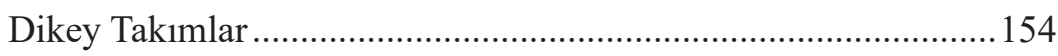

Oluşturulma Nedenlerine Göre Takım Türleri...................................... 155

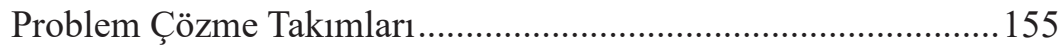

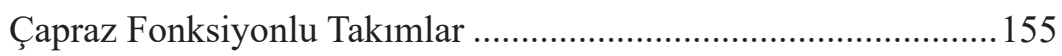

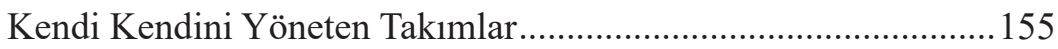

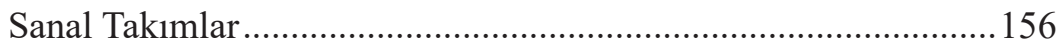

Genel Farklılıklarına Göre Takım Türleri..........................................156

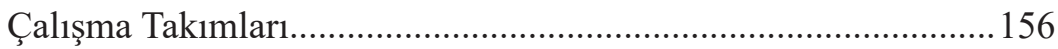

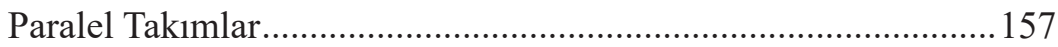

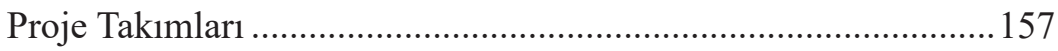

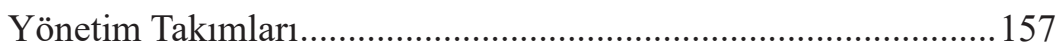

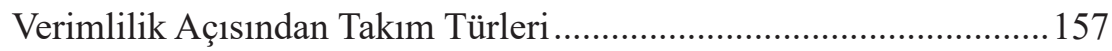

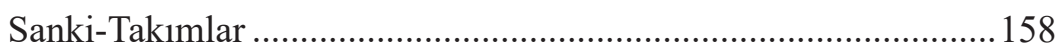

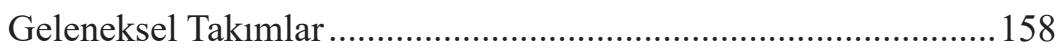

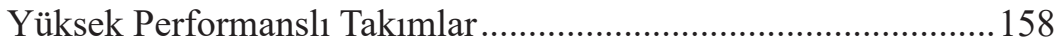




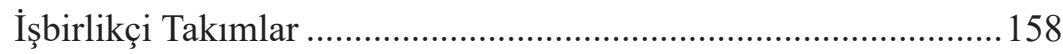

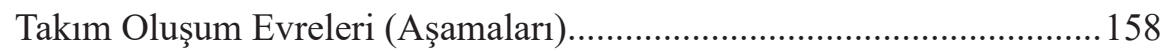

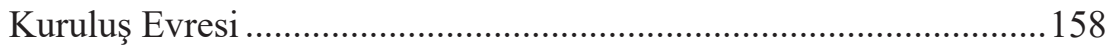

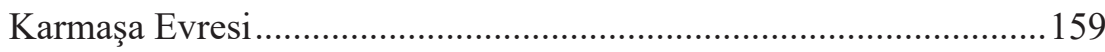

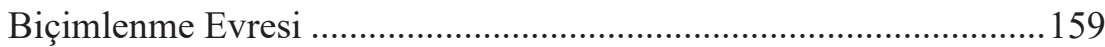

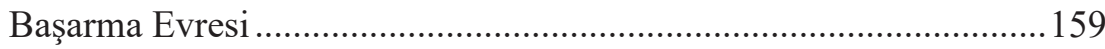

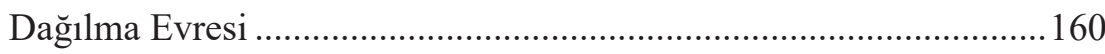

Takım Çalışmasının Birey Açısından Önemi.............................................160

Takım Çalışmasının Örgütler Açısından Önemi ........................................ 161

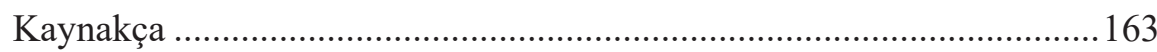

\section{BÖLÜM 7}

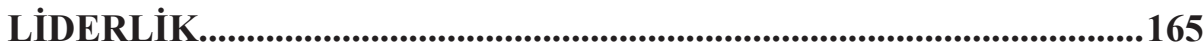

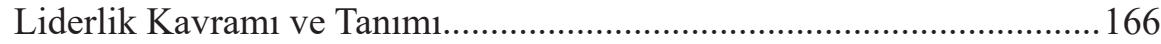

Lider İle Yönetici Arasındaki Farklılıklar...............................................167

Güç ve Liderin Sahip Olabileceği Güç Türleri ..........................................168

Liderin Pozisyonuna Dayalı Güç Türleri.............................................. 168

Liderin Sahip Olabileceği Bireysel Güç Türleri.................................169

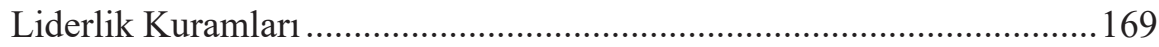

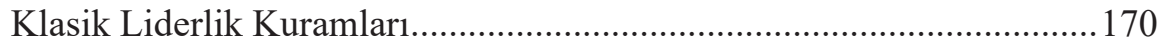

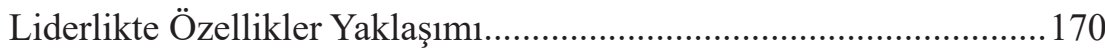

Liderlikte Davranışsal Yaklaşım...........................................................171

Ohio State Üniversitesi Liderlik Çalışmaları ...................................171

Michigan Üniversitesi Liderlik Çalışmaları ...................................172

Blake ve Mounton'un Yönetim Tarzı Matrisi ...............................173

Mcgregor' un X ve Y Kuramlar1 ..................................................175

Likert'in Dörtlü Yaklaşım Modeli ................................................176

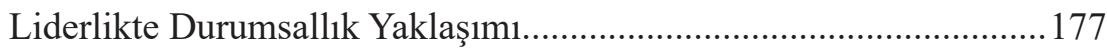

Fred Fiedler'in Etkin Liderlik Modeli............................................177

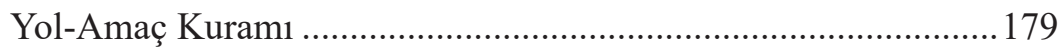

Vroom ve Yetton'un Liderlik Modeli ................................................ 180

Hersey ve Blanchard'ın Yaşam Döngüsü Kuramı............................ 183

Tannenbaum ve Schmidt'in Liderlik Doğrusu ................................. 186

Reddin'in Üç Boyutlu Lider Etkinliği Modeli ................................189

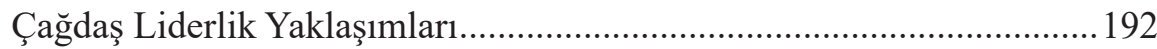

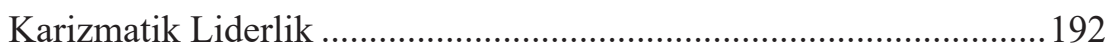

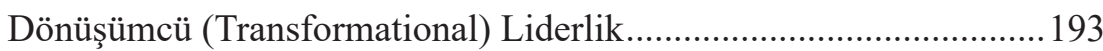

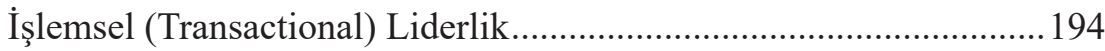




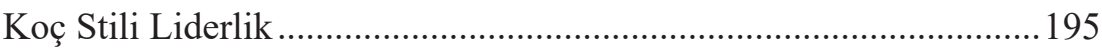

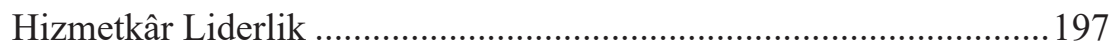

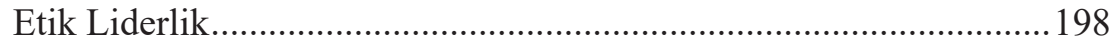

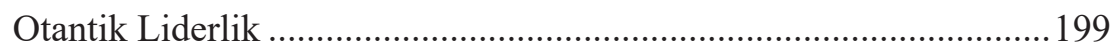

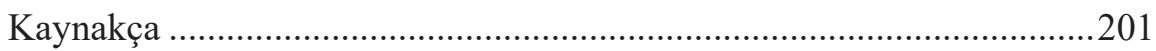

\section{BÖLÜM 8}

ÖRGÜTLERDE GÜÇ VE POLITIKA..................................................205

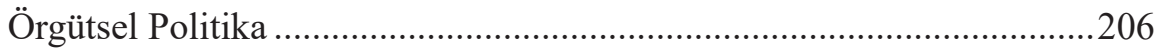

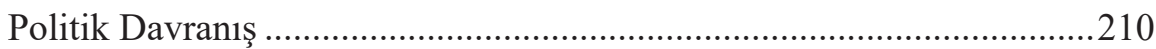

Politik Davranışların Ortaya Çıkma Nedenleri..........................................210

Politik Davranışın Ortaya Çıktığı Örgütsel Alanlar ve Faaliyetler...........212

Örgütsel Politika, Otorite ve Gücün İşleyişi ............................................212

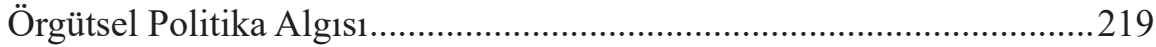

Örgütsel Politika Algısına İlişkin Model ..............................................220

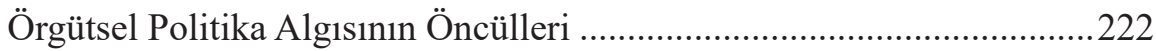

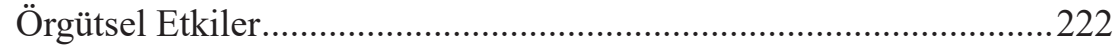

Görev ve Çalışma Çevresi Etkileri ....................................................223

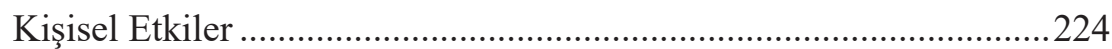

Örgütsel Politika Algısının Sonuçları ...................................................226

Örgütsel Politikanın Örgütler Açısından Sonuçları ..............................226

Örgütsel Politikanın Çalışanlar Açısından Sonuçları ..........................227

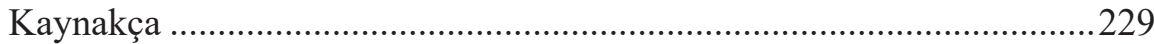

\section{BÖLÜM 9}

ÖRGÜT KÜLTÜRÜ, ÖRGÜT YAPISI VE GELİSTTIRME ....................233

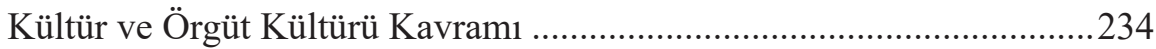

Örgüt Kültürünün Özellikleri ve İşlevleri...............................................234

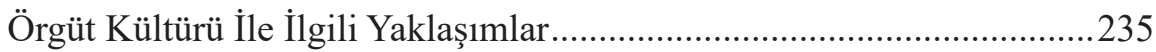

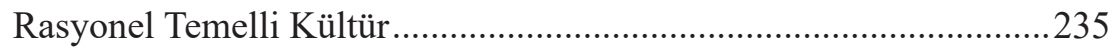

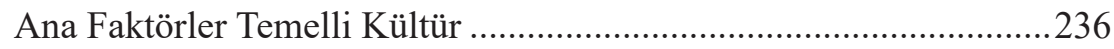

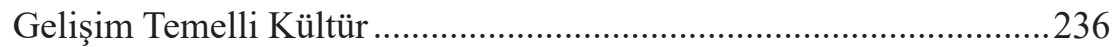

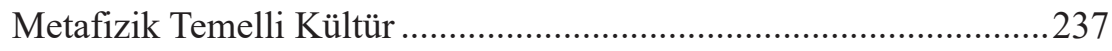

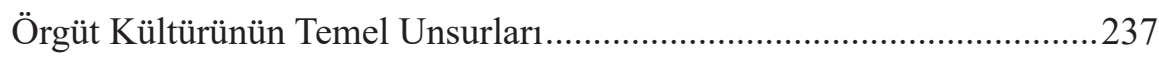

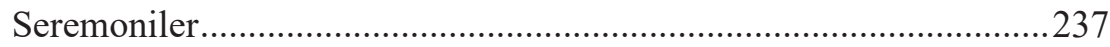

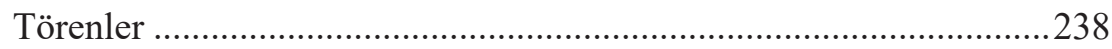

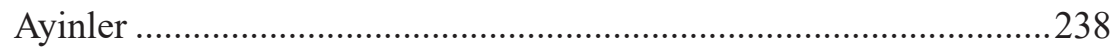

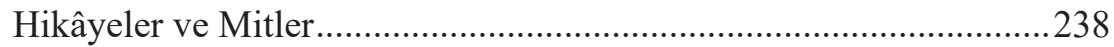




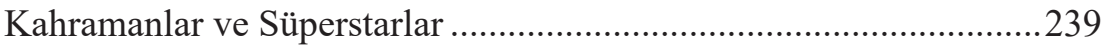

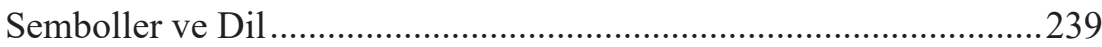

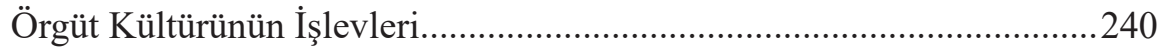

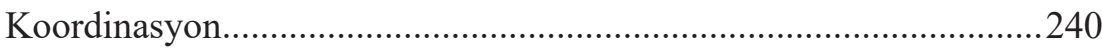

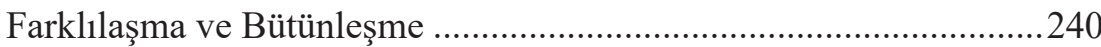

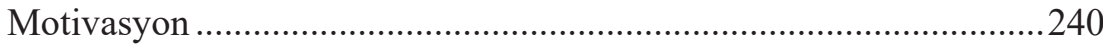

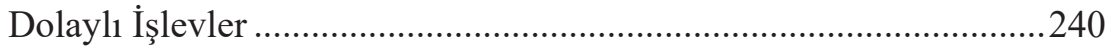

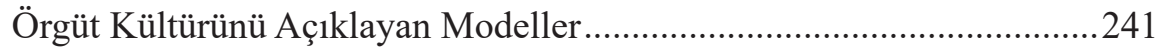

Ouchi Örgüt Kültürü Modeli (Kuram Z) .........................................241

Peters ve Waterman Örgüt Kültürü Modeli ........................................242

Parsons Örgüt Kültürü (Ag11) Modeli..................................................243

Deal ve Kennedy Örgüt Kültürü Modeli ..............................................24

Kilmann, Saxton ve Serpa Örgüt Kültürü Modeli .............................247

Miles ve Snow Örgüt Kültürü Modeli ...............................................247

Cameron ve Quinn Örgüt Kültürü Modeli...........................................249

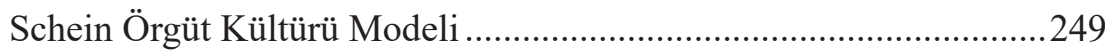

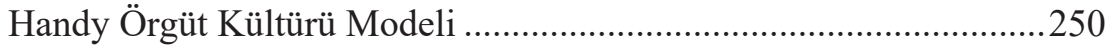

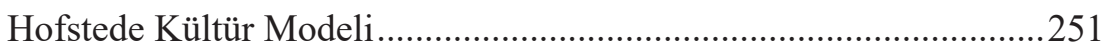

Örgüt Kültürünü Öğrenme ve Geliştirme ..............................................252

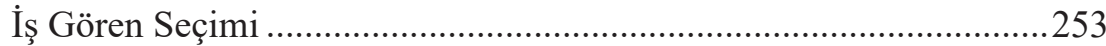

Üst Yönetimin Tutum ve Davranışları................................................253

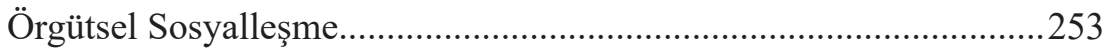

Örgüt Kültürü Konusunda Yapılan Araştırmalar ........................................254

Örgüt Kültürü Konusunda Yapılan Uluslararası Araştırmalar.............254

Örgüt Kültürü Konusunda Yapılan Ulusal Araştırmalar.......................255

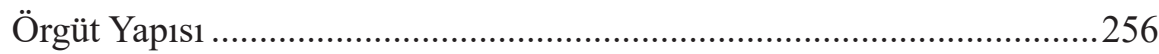

Örgüt Yapısını Oluşturan Unsurlar .........................................................257

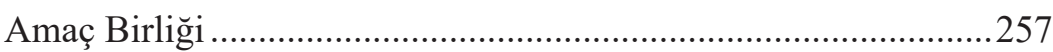

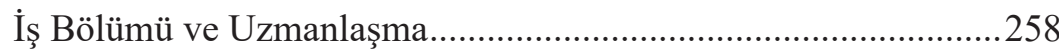

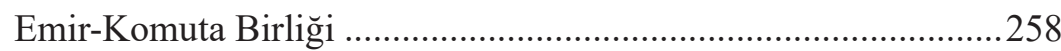

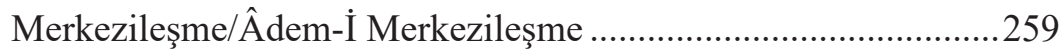

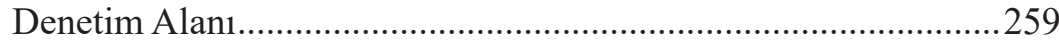

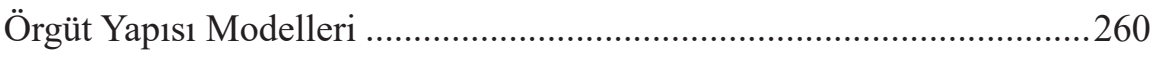

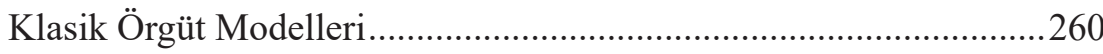

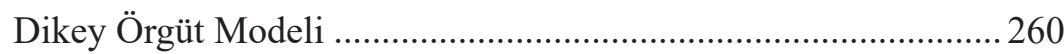

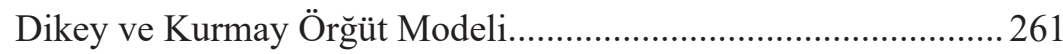

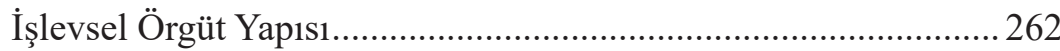

Dikey-İşlevsel Örgüt Yapısı.......................................................... 264 


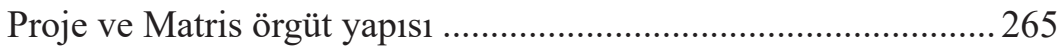

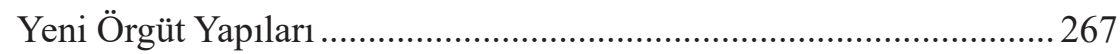

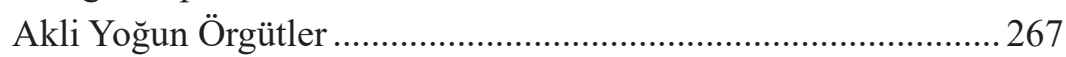

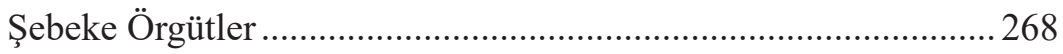

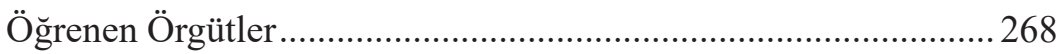

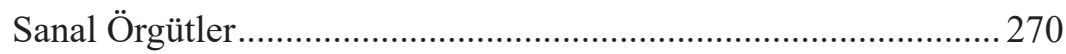

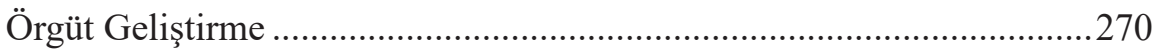

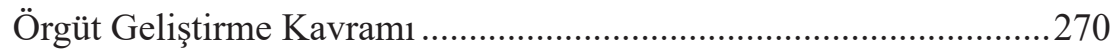

Örgüt Geliştirmenin Özellikleri ................................................................2.272

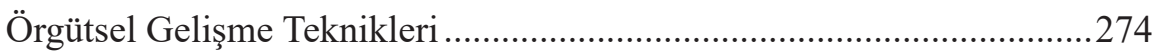

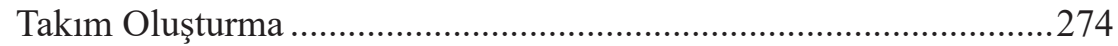

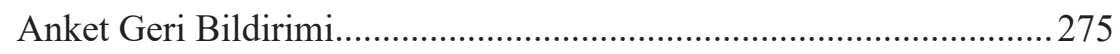

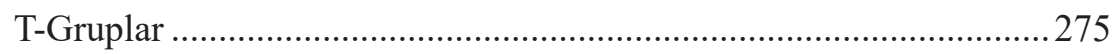

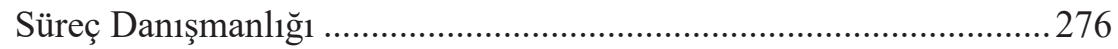

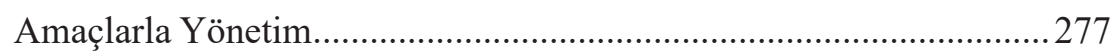

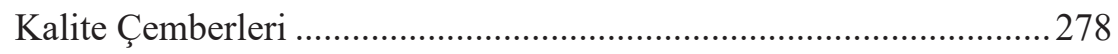

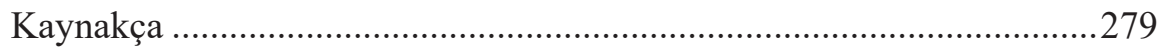

\section{BÖLÜM 10}

ÖRGÜTSEL STRES VE YÖNETIMİ .................................................283

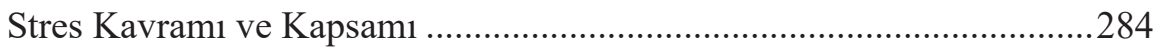

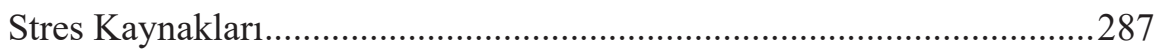

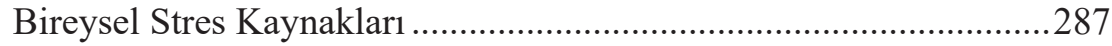

Bireysel Stres Kaynağı Olarak Kişilik ..........................................287

Bireysel Stres Kaynağı Olarak Diğer Faktörler.............................28

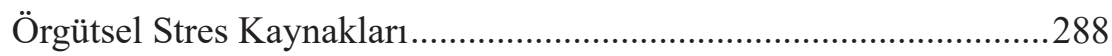

Örgüt Yapıs1 ve Örgüt İklimi İle İlgili Faktörler ............................2289

Fiziki Çevre Şartları İle İlgili Faktörler........................................28

Yapılan İş Niteliği İle İlgili Faktörler ..............................................2290

Örgütsel Çatışmaya Yol Açan Kariyer Gelişimi Faktörleri ............293

Örgütsel Çatışmaya Yol Açan İşletme İçi Faktörler ....................... 293

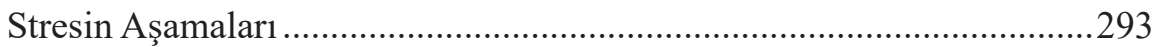

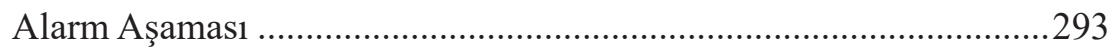

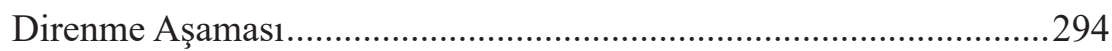

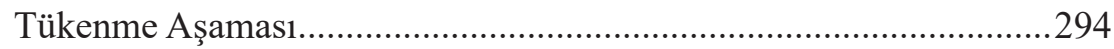

Stresin Örgütte Yol Açtı̆̆ Sonuçları......................................................295

Stresin Örgütte Yol Açtı̆̆ Sonuçları Doğrudan Sonuçları ..................295

Stresin Örgütte Yol Açtığ1 Sonuçları Dolaylı Sonuçlar ........................295 


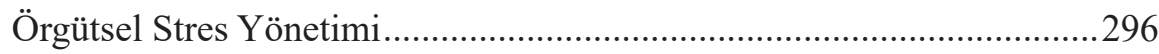

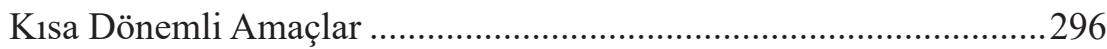

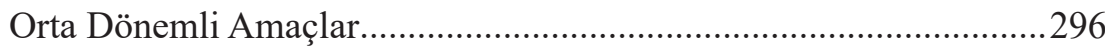

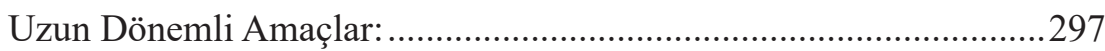

Stresi Önlemede Kullanılabilecek Örgütsel Önlemler..............................298

Kat1lımlı Yönetim (Participation Management) ..................................300

Amaçları Belirleme Faaliyetleri (Goal Setting Activities) ..................301

Rol Analizi ve Sinıflandırılması (Role Analysis) ................................301

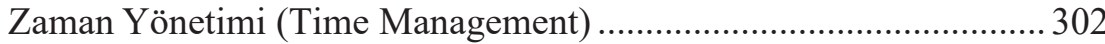

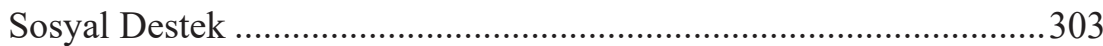

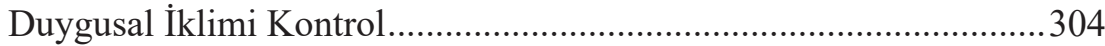

Stres Yönetimi Eğitimi (Stress Management Education) .....................304

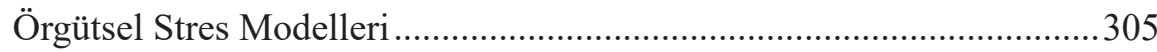

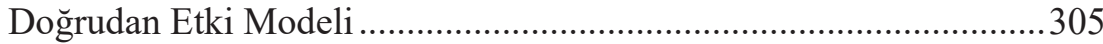

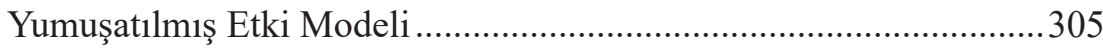

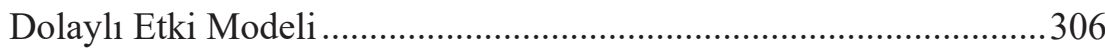

Dolaylı Yumuşatılmış Etki Modeli .........................................................306

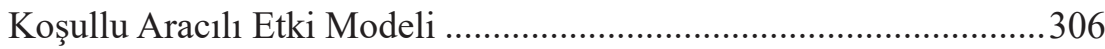

Sinırlı Aracılı Etki Modeli ....................................................................306

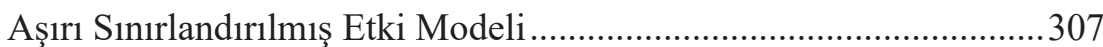

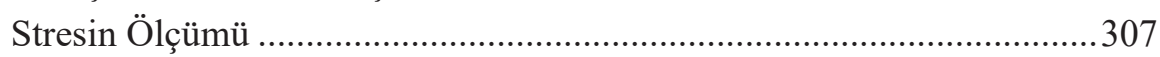

Performans Testleri İle Stresin Ölçümü............................................307

Fizyolojik ve Biyolojik Değişimler Yoluyla Ölçüm.............................307

Hayat Olayları Tablosu İle Ölçüm.........................................................308

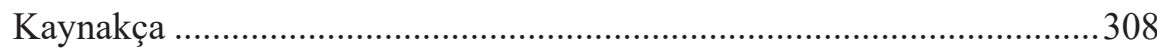

\section{BÖLÜM 11}

ÖRGÜTLERDE ADALET.........................................................................

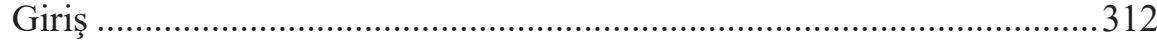

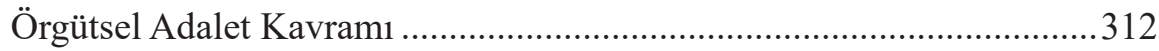

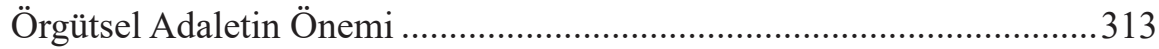

Örgütsel Adaletin Boyutları ......................................................................... 314

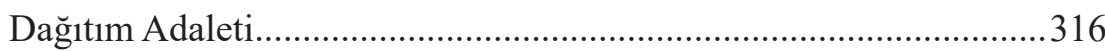

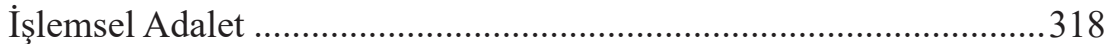

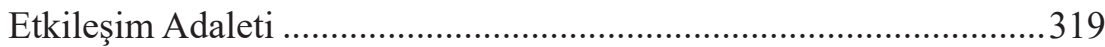

Bireyleraras1 Adalet ve Bilgisel Adalet ...............................................320

Örgütsel Adaletin Temelini Oluşturan Kuramlar .........................................322

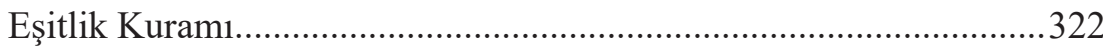




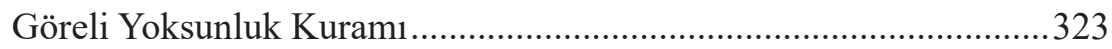

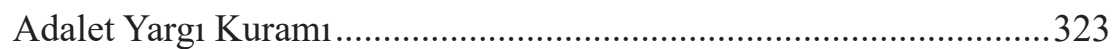

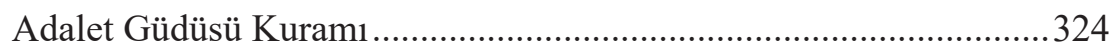

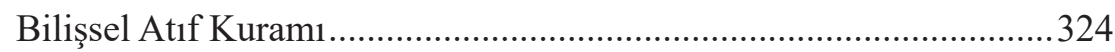

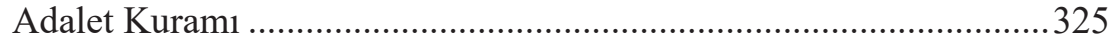

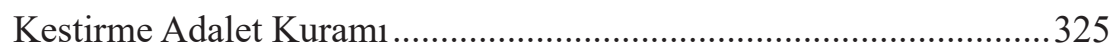

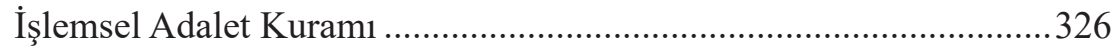

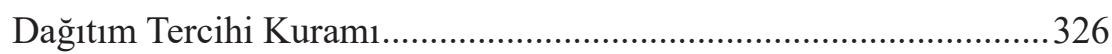

Örgütsel Adalet İle İlgili Kuramsal Yaklaşımlar.........................................327

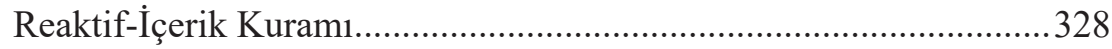

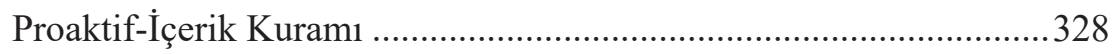

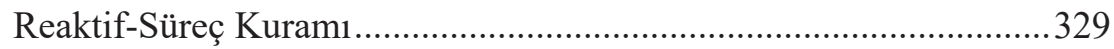

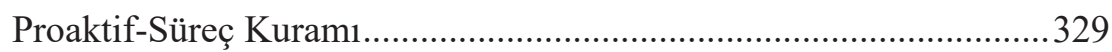

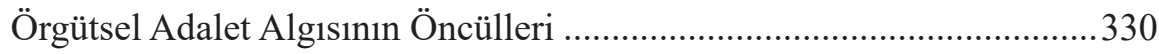

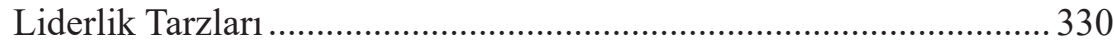

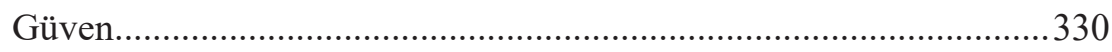

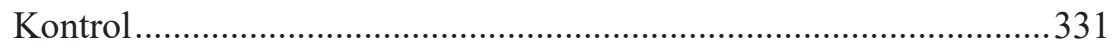

Örgütsel Adalet Algısının Örgütsel Sonuçları............................................331

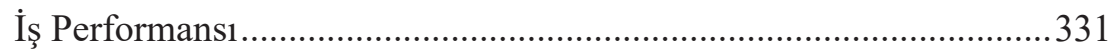

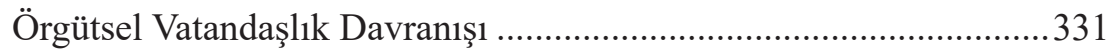

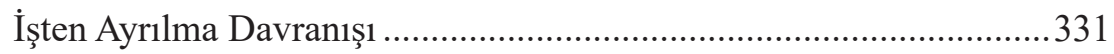

Örgütsel Adaletin Çeşitli Değişkenler İle İlişkisi .....................................332

Örgütsel Adalet ve Ahlaki Değerler İlişkisi.........................................332

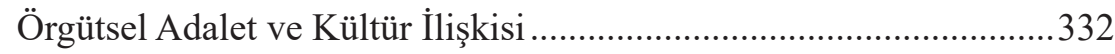

Örgütsel Adalet ve Motivasyon/Performans İlişkisi.............................332

Örgütsel Adalet ve İşten Ayrılma Niyeti İlişkisi ...................................333

Örgütsel Adalet ve Örgütsel Bağlı̆lı İlişkisi......................................333

Örgütsel Adalet ve Örgütsel Güven İlişkisi ...........................................334

Örgütsel Adalet ve Ödüllendirme Sistemleri İlişkisi ............................334

Örgütsel Adalet ve İş Doyumu İlişkisi.................................................335

Örgütsel Adaletin Ölçümü ..........................................................................335

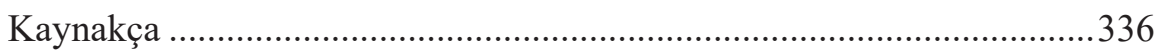

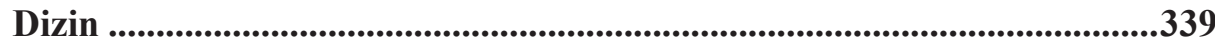




\section{KAYNAKÇA}

Arslantaş, C. C., \& Pekdemir, I. (2007). Dönüşümcü liderlik, örgütsel vatandaşlık davranışı ve örgütsel adalet arasındaki ilişkileri belirlemeye yönelik görgül bir araştırma. Anadolu Üniversitesi, Sosyal Bilimler Dergisi, 7(1), 261-286.

Aryee, S., Budhwar, P.S., \& Chen, Z.X. (2002). Trust as a mediator of the relationship between organizational justice and work outcomes: Test of a Social Exchange Model. Journal of Organizational Behavior, 23, 267-285.

Beugre, C. (1998). Managing Fairness in Organizations. Quorum Books Co., Westport, CT.

Bianchi, E.C., \& Brockner, J. (2012). "In the eyes of the beholder? The role of dispositional trust in judgments: Procedural and interactional fairness". Organizational Behavior and Human Decision Process, 118, 46-59.

Bies, R. \& Moag, J. (1986). Interactional justice: Communication criteria of fairness. In R. Lewicki, B. Sheppard \& M. Bazerman (Eds.), Research on negotiation in organizations (pp. 4355). Greenwich, CT: JAI Press.

Blader, S.L., \& T.R. Tyler (2003). 'What constitutes fairness in work settings? A four-component model of procedural justice', Human Resource Management Review, 13, 107-126.

Celani, A., Deutsch-Salamon, S., \& Sing, P. (2008). "In justice we Trust: A model of the role of trust in the organization in applicant reactions to the selection process". Human Resource Management Review, 18, 63-76.

Cohen-Charash, Y., \& Spector, P. (2001). The role of justice in organizations: A meta-analysis. Organizational Behavior and Human Decision Processes, 86, 278-321.

Colquitt, J.A. (2001). On the dimensionality of organizational justice: A construct validation of a measure. Journal of Applied Psychology, 86, 386-400.

Colquitt, J.A., Conlon, D.E., Wesson, M.J., Porter, C.O., \& Ng, K.Y. (2001). Justice at the millennium: A meta-analytic review of 25 years of organizational justice research. Journal of Applied Psychology, 86, 425- 445.

Cropanzano, R., Rupp, D.E., Mohler, C.J., \& Schminke, M. (2001). Three roads to organizational justice. In G. Ferris (Ed.), Research in personnel and human resources management, vol. 20, 1-113. Greenwich, CT: JAI Press.

Crosby, F. (1976). A model of egoistical relative deprivation. Psychological Review, 83, 85-113.

Çakır Ö. (2006). Ücret Adaletinin İs Davranışları Üzerindeki Etkileri. Kamu-İş Kamu İşletmeleri İşverenleri Sendikası, Ankara.

Deutsch, M. (1975). Equity, equality, and need: What determines which value will be used as the basis of distributive justice? Journal of Social Issues, 31(3), 137-149.

Dailey, R.C., \& Kirk, D.J. (1992). Distributive and procedural justice as antecedents of job dissatisfaction and intent to turnover. Human Relations, 45(3), $305-317$.

Dilek, H. (2005). Liderlik tarzlarının ve adalet algısının örgütsel bağl1lık, iş tatmini ve örgütsel vatandaşlık davranışı üzerine etkilerine yönelik bir araştırma. (Yayınlanmamış Doktora Tezi). Gebze İleri teknoloji Enstitüsü Sosyal Bilimler Enstitüsü.

Festinger, L. (1957). A theory of cognitive dissonance. Evanston, Row, Peterson.

Folger, R. (1986). Mediation, arbitration, and the psychology of procedural justice. In R. Lewicki, M. Bazerman, \& B. Sheppard (Eds.), Research on negotiation in organizations (Vol. 1, pp. 57-79). Greenwich, CT: JAI Press.

Folger, R. \& Cropanzano, R. (2001). Fairness theory: Justice as accountability. In J. Greenberg \& R. Cropanzano (Eds.), Advances in organizational justice (pp. 89-118). Stanford, CA: Stanford University Press.

Folger, R. \& Cropanzano, R. (1998). Organizational Justice and Human Resource Management, Sage, Thousand Oaks, CA.

Folger, R., \& Konovsky, M. A. (1989). Effects of procedural and distributive justice on reactions to pay raise decisions. Academy of Management Journal, 32, 115-130.

Folger, R., Rosenfield, D., Rheaum, K., \& Martin, D. (I983). Relative deprivation and referent 
cognitions. Journal of Experimental Social Psychology. 19, 172-184.

Giacobbe-Miller, J. (1995). A test of the group values and control models of procedural justice from the competing perspective of labor and management. Personnel Psychology, 48, 115-142.

Gilliland, S. (2008). The tails of justice: a critical examination of the dimensionality of organizational justice constructs. Human Resource Management Review, 18, 271-281.

Greenberg, J. (1993). The social side of fairness: Interpersonal and informational classes of organizational justice. In R. Cropanzano (Ed.), Justice in the workplace: Approaching fairness in human resource management (pp. 79-103). Hillsdale, NJ: Erlbaum.

Greenberg, J. (1990). Organizational Justice; Yesterday, Today and Tomorrow. Journal of Management, 16(2), 399-432.

Greenberg, J. (1987). A taxonomy of organizational justice theories. Academy of Management Review, 12, 9-22.

Goodman, P. S. (1974). An examination of referents used in the evaluation of pay. Organizational Behavior and Human Performance, 12(2), 170-195.

Güler, B.K. (2009). Pozitif Psikolojik Sermaye: Tanımı, Bileşenleri ve Yönetimi. Aşkın Keser, Gözde Yılmaz, Şenay Yürür. (Editörler). Çalışma Yaşamında Davranış Güncel Yaklaşımlar, İzmit: Umuttepe Yayınları.

Gürgen, H., Kırel, Ç., Uztuğ, F., \& Orhon, N. (2003). Halkla İlişkiler ve İletişsim. Anadolu Üniversitesi Yayını No:1482, Açıköğretim Fakültesi Yayını No:792, 1. Baskı, Eskişehir.

Homans, G. C. (1961). Social behavior: Its elementary form. New York: Harcourt Brace and World.

Irak, D. U. (2004). Örgütsel adalet: Ortaya çıkışı, kuramsal yaklaşımlar ve bugünkü durumu. Türk Psikoloji Yazıları, 25-43.

İçerli, L. (2010). Örgütsel adalet: Kuramsal bir yaklaşım. Girişimcilik ve Kalkınma Dergisi, $5(1), 67-92$.

İnce, M., \& Gül, H. (2005). Yönetimde yeni bir paradigma: Örgütsel bağllllk. Konya: Çizgi Kitabevi.

İşbaşı, J. Ö. (2001). Çalışanların yöneticilerine duydukları güvenin ve örgütsel adalete ilişkin alg1lamalarının vatandaşlık davranıșının oluşumundaki rolü. Yönetim Araștırmaları Dergisi, 1(1), 51-73.

Konovsky, M. (2000). Understanding procedural justice and its impact on business organizations. Journal of Management, 26(3), 489-518.

Konovsky, M.A., \& Cropanzano, R. (1991). Perceived fairness of employee drug testing as a predictor of employee attitudes and job performance. Journal of Applied Psychology, 76, 698-707.

Karaeminoğulları, A. (2006). Öğretim elemanlarının örgütsel adalet algıları ile sergiledikleri üretkenliğe aykırı davranışlar arasındaki ilişki ve bir araştırma. (Yayımlanmamış Yüksek Lisans Tezi). İstanbul Üniversitesi, Sosyal Bilimler Enstitüsü, İstanbul.

Lerner, M. J. (1980). The belief in a just world: A fundamental delusion. New York: Plenum Press

Leventhal, G. S. (1980). What should be done with equity theory? New approaches to the study of fairness in social relationships. In K. Gergen, M. Greenberg, \& R. Willis (Eds.), Social exchange: Advances in theory and research (pp. 27-55). New York: Plenum Press.

Leventhal, G.S., Karuza, J. Jr. \& Fry, W.R. (1980). Beyond fairness: A theory of allocation preferences. In G. Mikula (Ed.), Justice and social interaction (pp. 167-218). New York: Springer-Verlag.

Luthans, F. (2002). Positive organizational behavior: Developing and managing psychological strengths. Academy of Management Executive, 16(1), 57-72.

Markovsky, B. (1985). Toward a multilevel distributive justice theory. American Sociological Review, 50, 822-839.

Martocchio, J. J., \& Judge, T. A. (1995). When we don't see eye to eye: Discrepancies between supervisors and subordinates in absence disciplinary decisions. Journal of Management, 21, 251-278.

Milkovich, G.T., \& Newman, J.M. (1987). Compensation. Plano, Texas: Business Publications, Inc. 
Moorman, R. H. (1991). Relationship between organizational justice and organizational citizenship behaviors: Do fairness perceptions influence employee citizenship?. Journal of Applied Psychology, 76, 845-855.

Niehoff, B.P., \& Moorman, R.H. (1993). Justice as a mediator of the relationship between methods of monitoring and organizational citizenship behavior. Academy of Management Journal, 36, 527-556.

Organ, D. W., \& Moorman, R. H. (1993), "Fairness and organizational citizenship behavior: What are the connections?" Social Justice Research, 6(1), 5-18.

Özdevecioğlu, M. (2003). Algılanan örgütsel adaletin bireylerarası saldırgan davranışlar üzerindeki etkilerinin belirlenmesine yönelik bir araştırma. Erciyes Üniversitesi İktisadi ve İdari Bilimler Fakültesi Dergisi, 21, 77-96.

Özen, J. (2002). Adalet kuramlarının gelişimi ve örgütsel adalet türleri, Hukuk Felsefesi ve Sosyolojisi Arşivi 5, İstanbul Barosu, İstanbul, 107-117.

Özmen, Ö. N. T., Arbak, Y., \& Özer, P. S. (2007). Adalete verilen değerin adalet algıları üzerindeki etkisinin sorgulanmasına ilişkin bir araştırma. Ege Akademik Bakış, 7(1), 17-33.

Pillai, R., Scandura, T.A., \& Williams, E.A. (1999). Leadership and organizational justice: similarities and differences across cultures. Journal of International Business Studies, 30(4), 763-779.

Pillai, R., \& Williams, E.A. (1996). Performance beyond Expectations? A Study of Transformational Leadership, Fairness Perceptions, Job Satisfaction, Commitment, Trust, and Organizational Citizenship Behavior. The National Academy of Management Meeting, Cincinnati, $\mathrm{OH}$

Polat, S. (2007). Ortaöğretim öğretmenlerinin örgütsel adalet algıları, örgütsel güven düzeyleri ile örgütsel vatandaşlık davranışları arasındaki ilişki. Yayımlanmamış doktora tezi, Kocaeli: Kocaeli Üniversitesi Sosyal Bilimler Enstitüsü.

Seligman, M.i \& Csikzentmihalyi, M. (2000). Positive psychology: An introduction. American Psychologist, 55, 5-14.

Seymen, O., Girgin, G.K., Giritlioğlu, İ., \& Aksu, M. (2009). İşgörenlerin etkileşim adaleti algılarının örgütsel bağlılıkları üzerindeki etkisinin incelenmesi: Çanakkale ilinde faaliyet gösteren otel işletmelerinde bir araştırma. 17. Ulusal Yönetim ve Organizasyon Kongresi, 21-23 Mayıs, Osmangazi Üniversitesi, Eskişehir.

Sweeney, P.D., \& McFarlin, D. B. (1997). Process and outcome: Gender differences in the assessment of justice. Journal of Organizational Behavior, 18, 83-98.

Thibaut, J., \& Walker, L. (1975). Procedural Justice: A Psychological Analysis. Hillsdale, NJ: Erlbaum

Tyler, T.R. (1994). Psychological models of the justice motive: Antecedents of distributive and procedural Justice. Journal of Personality and Social Psychology, 57(5), 850-863.

Tyler, T.R., \& Bies, R. J. (1990). Beyond formal procedures: The interpersonal context of procedural justice. In J. S. Carroll (Ed.), Applied social psychology and organizational settings (pp. 77-98). Hillsdale, NJ: Lawrence Erlbaum.

Tyler, X R. \& Lind, E. A. (1992). A relational model of authority in groups. In M. Zanna (Ed.), Advances in experimental social psychology (Vol. 25, pp. 115-192). New York: Academic Press.

Viswesvaran, C., \& Ones, D. S. 2003. Examining the construct of organizational justice. Journal of Business Ethics, 38, 193-203.

Walster, E., \& Berscheid, E. (1973). New directions in equity research. Journal of Personality and Social Psychology, 25(2), 151-176.

Welbourne, T.M., Balkin, D.B., \& Gomez-Mejia, L.R. (1995). Gainsharing and mutual monitoring: A combined agency-organizational justice interpretation. Academy of Management Journal, 38, 881-899.

Wright, T. A. (2003). Positive organizational behavior: An idea whose time has truly come. Journal of Organizational Behavior, 24, 443-442.

Yavuz, E. (2010). Kamu ve özel sektör çalışanlarının örgütsel adalet algılamaları üzerine bir karşılaştırma çalışması. Doğuş Üniversitesi Dergisi, 11(2), 302-312. 